William was a renowned lecturer. Prof. Cole had two sets of manuscript notes of his lectures (c. 1770), one of 280 pages, testifying to the appreciation and diligence of two of his students.

The nineteenth and twentieth centuries have produced a voluminous literature in every branch of zoology. The Library contains beautiful monographs in many languages. It is also rich in biographical and bibliographical works. Among the latter may be mentioned the Index Catalogue of the Library of the Surgeon General's Office, U.S. Army, Washington, which Prof. Cole used constantly. The first, second and third series, in 16, 21 and 10 volumes respectively, are present. Of the modern transcriptions and translations there are the works of Leonardo da Vinci, namely, "Codice sul volo degli Ucelli" (first edition, Rouveyre, Parigi, 1893), with the perfect facsimile of the original, "Dell'Anatomia, Fogli A"
(Parigi, 1898), "I Manoscritti di Leonardo da Vinci, della Reale Bibliotheca di Windsor. Dell'Anatomia, Fogli B" (Torino, 1901), half the series (13 volumes) of the "Fouillets inédits" (Paris, 1901) and "Quaderni d'Anatomia", six volumes (Christiania, 1911-16), a truly noble collection, as most of these are limited editions.

The above selection can give only a meagre idea of the richness and scope of this wonderful library. Prof. Cole's wishes were that it should not be dispersed, but should be available in toto, as it has been in the past, to scholars in the history of biological thought. 'This happy outcome has, we believe, been achieved by its acquisition by the University of Reading.

1 Macmillan and Co., Ltd., 1944; reprinted with corrections, 1949. ${ }^{2}$ J. Hist. Med. Yale, 13, 1 (1958).

\title{
OBITUARIES
}

Prof. W. N. Thomas, C.B.E.

Prof. W. N. Thomas, professor of engineering in University College, Cardiff, during 1928-50, died on Novomber 24.

His initial engineering training was as pupil and assistant of the Borough Engineer at Crewe.

During 1910-15 he lectured at the Universities of Nottingham and Birmingham. He then saw war service with the Royal Engineers in France and Flanders. He returned to university life at Birmingham and afterwards at Oxford, where he was chief assistant to Prof. Jenkin for five years and received the degrees of M.A. and D.Phil. He left Oxford to become principal assistant at the Building Research Station at Garston, and three years later, in 1928, he was appointed professor of engineering at Cardiff, a post in which he remained until his retirement in 1950.

His time at Cardiff was broken by war service. In 1939 he became scientific adviser to the Ministry of Home Security, and an expert on the effects of bombs on structures. He visited Moscow in 1941 and led a team of specialists to Japan in 1945 to report on the atom bomb damage at Nagasaki and Hiroshima. In 1946 his war work was recognized by the award of the American Medal of Froedom and he was made C.B.E.

On retirement from the University of Wales, Norman Thomas became president of the South Wales Institute of Engineers, and presided over the difficult negotiations which led to its amalgamation with the South Western Society of Mining Engineers. He continued his association with the Home Office and became chief scientific adviser for Wales on civil defence. He relinquished this appointment only a year ago. $\mathrm{He}_{e}$ was also active in the affairs of the Institution of Civil Engineers and made a number of journeys abroad on its behalf.

His academic interests were well spread. Norman Thomas was an authority on the effect of frost on materials, and he published many papers on the mechanical properties of materials. Ho was author of a well-known text-book on surveying, and completed a further revision within a year of his death. He also wrote a book on bridges and was interested in military bridging. While at Cardiff he succeeded in having constructed an addition to his somewhat modest laboratories, and he lived long enough to take part in a token demolition of the wooden walls which were his academic inheritance; and to see the domolition proper commence. His colleagues greatly regret that he did not survive a few more years to see the splendid new laboratories which will replace them.

In personal characteristics, Norman Thomas was modest and retiring, but his quietly expressed opinions were well received by his colleagues, and he had an unusual capacity for inspiring other people's affection.

$$
\text { C. GURNEY }
$$

\section{Dr. Pierre A. Chappuis}

The Swiss zoologist Dr. P. A. Chappuis, who died at Zurich on July 9, 1960, was for many years assistant director of the Institut de Spéologie at Cluj, Rumania, where he also acted as Swiss Consul. At the time of his death he was attached to the Centre National de la Recherche Scientifique as director of research and assistant director of the Laboratoire Souterrain de Moulis (Ariège), France.

He was born on September 5, 1891, at Saint-Cloud, Seine-et-Oise, France, where his father was assistant director of the International Bureau of Weights and Measures. Educated in Switzerland, he obtained his doctorate at the University of Basle in 1920; his thesis on the fauna of the subterranean waters in the neighbourhood of Basle was prepared under Prof. F. Zschokke. The following year he joined the staff of the recently created Institut de Spéologie at Cluj and in 1927 he succeeded $R$. Jeannel as assistant director. He remained at his post when, following the Treaty of Vienna, a large part of Transylvania was ceded to Hungary and his Rumanian colleagues went into exile (1940-45). E. Racovitza, the founder and first director of the Institut, died in 1947, and political events compelled Chappuis to leave Rumania in 1948.

Until serious thyroid trouble put an end to strenuous activity, he was a great traveller. In 1921 he and A. David explored the region of the White Nile. In 1929 he joined R. Jeannel and Ch. Alluaud in an expedition to the Sahara. In 1931 he and Alluaud crossed the Sahara and collected extensively in the regions of the Upper Volta and Ivory Coast. 
In $1932-33$ he accompanied Jeannel and Arambourg on their expedition to the Rivor Omo and climbed Mt. Elgon. $\mathrm{H}_{\Theta}$ and his colleagues visited hundreds of caves in little-known or unexplored parts of Transylvania, notably in tho Bihar Mountains, and in old Serbia.

A fuller account of his life, together with a complete list of his numorous scientific publications, will appear in a memorial part of the Annales de Spéle. ologie. He wrote the third volume of Thienemann's "Die Binnengewässer", ontitled "Die Tierwelt der unterirdischen Gewässer" (Stuttgart, 1927). In the same yoar he also contributed the soction on Anaspidacea to Kakonthal and Krumbach's "Handbuch de Zoologie". He was an authority on various groups of freshwater and subterranoan Crustacea, especially harpacticids, bathynellids and isopods. His discovery, in 1942, of the true habitat of Bathynella and other minute animals that occur sporadically in wells, springs or caves opened a new field of investigation. Since then numerous now or littloknown interstitial animals, freshwater and marine, have been discovered in many parts of the world. Many of the Crustacea, including a Europoan spocies of Mystacocarida, were describod by Chappuis and his collaborators and his last years in France were excesdingly productive ones.

In 1922 he married Heidie Spinnler, of Basle; their son, Piorro, rosides in Basle, and their daughter is married to an English architect.

Isaber.taA Gornon

\section{Dr. Gertrude L. Elles, M.B.E.}

THE doyen of women geologists, Dr. Gertrude L, Filles, emeritus reader in the University of Cambridgo and honorary Follow of Newnham College, died at Helensburgh on November 18, in her eighty-ninth year. She entered Newnham as a scholar in 1891 and remained, with few interruptions, residont in Cambridge until a few weeks bofore her death.

She obtained first-class honours in Part II of the Natural Sciences Tripos (Geology) in 1895 and for the next few years was associated with Lapworth at Birmingham and with Törnquist and others in Sweden. This initiated the work on graptolites for which she is so widely known, and she soon com- menced with Dame Fthel Shakespeare the propara tion of the Palrontographical Society's monograph on British graptolites under the editorship of Prof. Lapworth. The ten descriptivo parts of this classic work appoared with extraordinary regularity between 1901 and 1914 and established her position as a world authority on theso fossils. Of a dozon or so smaller publications on them, the most significant was her "Graptolite Faunas of the British Isles" (Geologists" Association, 1922), which has oxorcisod a profound influence on subsequent work on their faunal succession and evolution.

Nevertheless, Dr. Elles's interost in fossils was pre-ominently that of the field geologist and stratigrapher, and, concurrently with her work on the graptolites, her invostigations on Lower Palæozoic stratigraphy in Wales and the Welsh Borderland resulted in several papers on the geology of areas around Iudlow, Conway, Bala and Builth. Rolativoly lato in her career, she turned to a completely new field in 'hard-rock geology', and jointly with Prof. C. F. Tilloy published a notable contribution on metamorphism in relation to structure in the Scottish Highlands.

Dr. Ellos was closely associated with the Sedgwick Museum (or its forerunner, the Woodwardian Museum) for nearly seventy yoars. Hor standing in the Depart. ment of Goology was formalized by her appointment, under the new statutes, to a University lectureship in 1926 ; t $\oplus$ n years later, she became the first woman reader in the University. Few who have graduated in the Cambridge Department of Geology during this long period but were influenced by her enthusiasm as lecturer or supervisor; and many were drawn to Cambridge as postgraduate students to work under her direction. She inspired great affection among her colleagues, and as a teacher she will be remembered for her vitality, forthright manner and clarity of exposition.

She held the degree of doctor of science of Dublin and of Cambridge. When the Geological Society of London extended its followship to womon in 1919, she was one of the small but distinguished group at onco admitted, and she was in the same year the first woman to receive the Society's Murchison Medal. She was president of Section C (Geology) of the British Association in 1923.

O. M. B. Bulman

\section{NEWS and VIEWS}

\begin{abstract}
Royal Society :
New Gold Medal

THE Council of tho Royel Society has accepted an offer by the Trustees of the Leverhulme Trust Fund to mark the occasion of the Royal Society's 'Tercentenary by the award of a gold medal. Undor the terms of the offer, the medal is "for award by the Society, evory three years, to the individual who in the opinion of its Council shall have made the most significant contribution in the field of pure or applied chemistry or engineering including chemical engineering. The medal, which will be in gold, will be accompanied by a monetary award of five hundred pounds". The Council has made the first award of the medal to Sir Cyril Hinshelwood, who rotired as president of the Royal Socioty on November 30, for his outstanding contributions to physical chemistry.
\end{abstract}

\section{Officers}

Str Howard Florey, president of the Royal Society, has appointed the following vice-presidents for the year ending Novernber 30, 1961 : Sir Alexander Fleck, treasuror of the Royal Society, formerly chairman of Imperial Chemical Industries, Ltd. ; Sir Lindor Brown, biological secretary of the Royal Society, Waynflete professor of physiology in the University of Oxford ; Sir William Hodge, physical secretary of the Royal Society, Lowndean professor of goometry and astronomy in the University of Cambridge ; Sir Patrick Linstead, foreign secretary of the Royal Society, rector of the Imperial College of Science and Technology, London; Prof. 'T. M. Harris, professor of botany in the University of Roading; Dame Kathleen Lonsdale, professor of chemistry at University College, Iondon. 